\title{
Relationship between Phonological Awareness and Related Factors in Korean First to Third Graders
}

\author{
Seunghee $\mathrm{Ha}^{\mathrm{a}}$, Geum-Bin $\mathrm{So}^{\mathrm{b}}$ \\ ${ }^{a}$ Division of Speech Pathology and Audiology, Audiology and Speech Pathology Research Institute, Hallym University, Chuncheon, Korea \\ ${ }^{b}$ Graduate Program in Speech Language Pathology, Hallym University, Chuncheon, Korea
}

\author{
Correspondence: Seunghee $\mathrm{Ha}, \mathrm{PhD}$ \\ Division of Speech Pathology and Audiology, \\ Audiology and Speech Pathology Research \\ Institute, Hallym University, 1 Hallimdaehak-gil, \\ Chuncheon 24252, Korea \\ Tel: $+82-33-248-2215$ \\ Fax: +82-33-256-3420 \\ E-mail: shha@hallym.ac.kr
}

Received: October 5, 2019

Revised: November 13, 2019

Accepted: November 13, 2019
Objectives: Phonological awareness is the ability to recognize and manipulate the sound structure of spoken words and shows a strong relationship with early literacy. Children's development of phonological awareness is affected by speech-language skills, intelligence, and environmental factors. This study aims to examine the relationship between phonological awareness and related factors; including speech-language skills, nonverbal intelligence, and social-economic status (SES) in 1st to 3rd graders and to identify which factors significantly predict phonological awareness. Methods: A total of 1281 st to 3 rd-grade students received a phonological awareness test, articulation and phonology test, receptive and expressive vocabulary tests, and nonverbal intelligence test. Information about the SES for each child was also obtained. Correlation analysis and stepwise multiple regressions were performed to examine which factors predict phonological awareness at the syllable and phoneme levels among articulation and phonology ability, receptive and expressive vocabulary, nonverbal intelligence, SES and grades. Results: The results indicated that receptive vocabulary and articulation, and phonology ability predict significantly phonological awareness at the syllable level. Also, expressive vocabulary and nonverbal intelligence significantly predict phonological awareness at the phoneme level. Conclusion: This study suggests that phonological awareness develops during the early primary school years, and shows close relationships with receptive and expressive vocabulary, articulation and phonology ability, and intelligence.

Keywords: Phonological awareness, Articulation and phonology, Vocabulary, Nonverbal intelligence, Social-economic status
음운인식이란 음성 언어로 실현된 단어의 음운구조를 알고 조작 할 수 있는 능력을 지칭한다(Bernthal, Bankson, \& Flipsen, 2017). 음운인식은 문자 해독과 높은 상관을 갖으며, 읽기능력을 예측하 는 강한 변인으로 밝혀져 언어병리학과 교육학 분야에서 활발하게 연구되고 있다(Bradley \& Bryant, 1983; Hogan, Catts, \& Little, 2005; Torgesen, Wagner, \& Rashotte, 1994; Whitehurst \& Lonigan, 1998). 음운인식과 읽기능력과의 관계를 살펴본 문헌에서는 보편적으로 음소 수준에서의 음운인식이 읽기능력에 대한 예측도가 높은 것으 로 보고된다(Kim, 2007; Wimmer, Landerl, Linortner, \& Hummer, 1991). 하지만 한국어는 자음과 모음을 음절단위(syllable unit)로 모아 쓰는 형식이기 때문에 음소뿐만 아니라 음절 수준에서의 음
운인식도 읽기능력을 유의하게 예측하는 변인으로 보고된다(Cho \& McBride-Chang, 2005). 일반적으로 4세부터 단어 수준에서의 음운인식이 발달하고, 연령이 증가하면서 점차 음절, 음소 수준에 서의 음운인식이 발달한다. 아동의 연령뿐만 아니라 음운인식은 아동의 말.언어, 인지, 환경적인 요인에 의해 영향을 받거나, 함께 발달하기 때문에 음운인식과 관련된 요인과 각 요인의 영향 정도를 확인하는 것이 필요하다.

음운인식에 대한 국내연구는 주로 단어, 음절, 초성-각운, 음절 체-종성, 음소 수준에서 합성, 탈락, 변별 과제를 중심으로 한국아 동의 발달을 살펴보았다(Ahn, Heo, Kim, \& Kim, 2011; Hong, Chon, Pae, \& Lee, 2002; Hong, 2001; Kim, Yoo, \& Kim, 2010; Kim \& Pae, 
2007). 국내연구에서 공통적으로 살펴본 음절과 음소 수준에서 한 국아동의 음운인식 발달을 개괄적으로 정리하면, 과제 유형에 따 라 연구결과가 다소 다르지만 음절은 4 세에는 평균 $30 \%$ 대의 낮은 정반응을 보이다가 5 세에 이르러서는 약 $65 \%$ 로 크게 향상되고 6 세 에는 대략 $95 \%$ 의 정반응을 보였다. 음소 수준에서는 6세 아동도 $20 \%$ 대의 낮은 정반응을 보이고 초등학교 저학년 기간 동안 점진 적으로 발달하여 4 학년에 이르러 $75 \%$ 이상의 정반응을 보였다 (Hong et al., 2002; Kim et al., 2010; Kim \& Pae, 2007). 따라서 음소 수준에서의 음운인식은 많은 수의 아동이 초등학교 저학년 동안 습득하면서 비교적 늦게 발달한다.

음운인식 과제를 정확하게 수행하기 위해서는 구어의 소리 정보 를 잘 지각하고 인식해서, 심상어휘집 내 말소리 정보와 배열규칙 과 관련된 음운 표상을 거쳐 목표반응을 정확하게 조음해야 한다. 따라서 음운인식은 조음음운 발달과 밀접한 관계를 보이고, 일부 말소리장애 아동은 음운인식의 발달이 지연되거나 문제를 보인다. 구체적으로 문헌에서는 4 세 이후에도 지속적으로 말소리 산출상 의 문제를 보이거나, 음운 표상 수준에서의 문제로 인해 말소리장 애를 보이는 경우 음운인식 발달상의 문제를 보이면서 학령기에 읽 기 장애로 진단될 가능성이 높다고 보고하였다(Anthony et al., 2011; Nathan, Stackhouse, Goulandris, \& Snowling, 2004; Preston \& Edwards, 2010; Schuele, 2004). 단어 내 말소리와 음소 배열규칙 에 대한 추상적 지식인 음운 표상은 단어의 뜻, 속성, 이름과 관련 된 의미 및 어휘 표상을 비롯한 언어적 속성과 상호보완적인 관계 를 맺으면서 발달해 나간다. 즉 음운 표상상의 문제로 인해 말소리 산출뿐만 아니라 어휘 습득상의 문제를 함께 보일 수 있다. 따라서 음운인식은 아동의 조음 및 어휘 발달과 밀접한 관련을 보이면서 발달하기 때문에 조음과 어휘상의 제한을 동시에 보이는 아동일수 록 음운인식상의 어려움을 보일 가능성이 높다. 실제로 선행연구 에서 언어장애를 동반한 말소리장애 아동의 경우 음운인식상의 문 제를 보일 가능성이 단순히 말소리장애만 보이는 아동과 비교해 높다고 보고하였다(Bird, Bishop, \& Freeman, 1995; Kim, Kim, Kwon, \& Lee, 2007; Kim, Shin, \& Ahn, 2005; Ko \& Kim, 2010; Larrivee \& Catts, 1999; Lewis, O’Donnell, Freebairn, \& Taylor, 1998).

아동의 조음과 언어능력과 함께 인지도 음운인식과 밀접한 관련 이 있다. 음운인식 과제를 정확하게 수행하기 위해서는 음운 정보 를 일시적으로 저장하고, 처리하고, 조작해야 하기 때문에 음운단 기기억과 음운작업기억과 같은 인지적 요소가 상당히 요구된다. 따라서 아동이 인지적으로 발달이 느리거나 제한이 있다면 음운인 식 또한 문제를 보일 수 있다. 최근 Lee와 $\mathrm{Ha}$ (2018) 연구에서 5-6세 말소리장애 아동은 일반아동과 비교해 음운단기기억과 음운작업
기억 과제에서 유의하게 낮은 수행력을 보였다. 또한 말소리장애와 일반아동 집단 모두 음운단기기억과 음운작업기억 과제 수행력과 수용 및 표현어휘량과 유의한 상관을 보였다. 이러한 결과는 음운 단기 및 작업기억과 같은 인지와 말.언어 능력이 서로 밀접한 관계 가 있으며, 인지, 말.언어 능력이 복합적으로 영향을 끼쳐 음운인식 상의 문제로 발전할 가능성을 제안하고 있다.

말.언어, 인지와 같은 아동의 내적인 요소와 함께 환경적인 요소 도 음운인식 발달에 큰 영향을 끼칠 수 있다. 환경적 요소 중 특히 사회경제적 수준에 초점이 맞추어져 연구가 많이 진행되었는데 대 다수의 국내외 연구에서 아동 가정의 사회경제적 수준이 낮을수 록 음운인식상의 문제를 보였다(Ahn, Lee, Kim, Shin, \& Park, 2007; Ahn \& Shin, 2008; Burt, Holm, \& Dodd, 1999; Gillon \& Schwarz, 2001; Lonigan, Burgess, Anthony, \& Barker, 1998; McDowell, Lonigan, \& Goldstein, 2007). 반면에 일부 연구에서는 부 모의 사회경제적 수준이 아동의 음운인식에 영향을 미치는 부분 은 미비하고 기타 다른 변인에 의해 영향을 받는다고 주장하기도 하였다(MacLean, Bryant, \& Bradley, 1987; Raz \& Bryant, 1990).

음운인식에 관한 문헌을 종합해보면, 음운인식은 아동의 말.언 어, 인지적 요소와 사회경제적 수준 등 다양한 아동의 내적, 외적 요 인에 의해 영향을 받으면서 발달한다. 특히 조음음운과 언어 발달 상의 문제를 보였던 어린 연령의 아동 중 일부 아동은 이후 음운인 식상의 문제로 연결되고 읽기 문제로 확대되는 점을 고려한다면 음운인식과 밀접한 관련을 보이는 요인을 찾고, 그 영향력을 살펴 보는 것은 의사소통장애 평가와 중재와 관련된 임상적 의사결정에 시사하는 바가 크다. 따라서 본 연구의 목적은 초등학교 저학년 아 동을 대상으로 음절과 음소 수준에서의 음운인식과 말.언어, 인지, 사회경제적 요인과의 관계를 살펴보고, 아동의 음운인식을 가장 잘 설명하는 요인을 찾고자 하였다.

\section{연구방법}

\section{연구대상}

본 연구는 초등학교 저학년인 1-3학년 아동을 대상으로 총 128 명을 포함하였다(1학년 52명, 2학년 54명, 3학년 22명). 전체 대상자 중 77명은 부모의 소득이 보건복지부가 지정한 중위소득 이상에 해당하는 아동이며, 51 명의 아동은 부모의 소득이 보건복지부가 지정한 차상위계층 이하에 속하는 아동이였다. 부모의 소득 수준 에 따라 일반(중위소득 이상)과 저소득가정으로 나누어 사회경제 적 요인을 살펴보았다. 또한 9명은 다문화가정 아동이였는데, 그 중 소득분위에 따라 8 명은 일반가정, 1 명은 저소득가정인 것으로 나 
Table 1. Demographic information of all the participants

\begin{tabular}{lcccc}
\hline & $\begin{array}{c}\text { 1st grade } \\
(\mathrm{N}=52)\end{array}$ & $\begin{array}{c}\text { 2nd grade } \\
(\mathrm{N}=54)\end{array}$ & $\begin{array}{c}\text { 3rd grade } \\
(\mathrm{N}=22)\end{array}$ & $\begin{array}{c}\text { Total } \\
(\mathrm{N}=128)\end{array}$ \\
\hline $\begin{array}{l}\text { Age }(\mathrm{mo}) \\
\text { Gender }\end{array}$ & $82.87(3.65)$ & $96.94(4.10)$ & $107.73(3.82)$ & $93.08(10.05)$ \\
Boy & 29 & 34 & 14 & 77 \\
Girl & 23 & 20 & 8 & 51 \\
SES & & & & \\
Middle or high & 31 & 33 & 13 & 77 \\
Low & 21 & 21 & 9 & 51 \\
\hline
\end{tabular}

Values are presented as mean (SD).

SES = social-economic status.

타났다. 연구대상자 정보는 Table 1과 같다.

\section{검사도구}

아동의 음운인식 능력을 살펴보기 위하여 한국어읽기검사(Korean Language Based Reading Assessment, KOLRA; Pae, Kim, Yoon, \& Jang, 2015) 중 음운인식 검사를 사용하였다. 음절과 음소 수준에서 합성과 탈락 과제를 통해 음운인식을 살펴보았다. 음절 수준에서는 탈락과 합성 각 5 문항으로 총 10 문항 실시하였으며, 음 소수준에서는 탈락과 합성 각 10 문항으로 총 20 문항 실시하였다.

아동의 조음능력을 살펴보기 위하여 아동용발음평가(Assessment of Phonology and Articulation for Children, APAC; Kim, $\mathrm{Pae}, \&$ Park, 2007)를 사용하였다. 본 연구에서는 아동의 언어능력 은 어휘에 국한 지어 수용·표현어휘력검사(Receptive \& Expressive Vocabulary Test, REVT; Kim, Hong, Kim, Jang, \& Lee, 2009)를 이 용하여 살펴보았다. 인지능력을 살펴보기 위해 한국어 비언어지능 검사 제2판(Korean version of Comprehensive Test of Nonverbal Intelligence second edition, K-CTONI-2; Park, 2014)을 실시하였 다. K-CTONI-2는 유추, 범주, 순서의 3가지 상위인지능력 영역을 그림과 도형의 두 가지 맥락을 통해 평가하는 총 6 가지 소검사로 구 성되어 있다. 그림과 도형의 두가지 맥락에서 유추, 범주, 순서 영역 을 살펴본 뒤 결과로 제시되는 그림척도와 도형척도 지수는 대부분 의 경우 서로 비슷한 결과를 보인다(Park, 2014, p. 35). 따라서 대상 자의 피로도를 최대한 줄이면서 비언어 인지능력을 타당하게 살펴 보기 위해 K-CTONI-2는 도형 맥락에서 3 개의 소검사, 도형유추, 도형범주, 도형순서 검사만을 실시하였다.

\section{자료수집}

본 연구의 자료는 검사자가 아동의 가정, 지역아동센터, 학교를 방문하여 조용한 독립된 공간에서 수집하였다. 음운인식 검사의
경우 본 문항을 실시하기 전 연습문항을 통하여 음운인식 검사의 과정을 충분히 이해하고 숙지시킨 후에 본 문항을 실시하였다. $\mathrm{APAC}$ 검사의 경우 아동의 반응을 모두 녹음하였으며, 이후 검사 자가 다시 녹음 자료를 듣고 원점수 및 자음정확도를 구하였다. KCTONI-2 검사의 경우 3 가지 소검사(도형유추, 도형범주, 도형순 서) 진행 시 3 개 연속 틀릴 경우 검사를 중단하고 채점하였다. 음운 인식 검사, APAC, REVT 및 K-CTONI-2 검사를 모두 진행한 아동 만 최종 연구대상자로 선정하였다. 부모 소득을 알아보기 위하여 검사자가 사전에 사례 면담지를 제작하였다. 사례 면담지 문항 중 양육환경 영역이 있으며, 이 영역에는 아동과 함께 사는 가족구성 원, 가정 내 총자녀수, 가정 내 총 수입, 해당 자녀의 한달 교육비 내 용이 포함되었다. 사례 면담지는 검사가 시작되기 전 연구설명서, 동의서와 함께 내용에 대한 설명을 한 후 아동의 보호자에게 직접 체크를 부탁하였다.

\section{자료분석 및 통계처리}

음운인식에 대한 자료 처리는 탈락과 합성 과제를 합쳐서 음절 과 음소 수준별로 분석하였다. 음절 수준에서의 음운인식은 총 10 점 만점이였으며, 음소 수준에서는 총 20점 만점으로 분석하고 정 반응률도 함께 계산하였다. 조음음운능력과 언어능력은 APAC과 REVT의 수용 및 표현검사의 원점수를 사용하였으며, 인지능력은 K-CTONI-2의 도형 과제인 도형유추, 도형범주, 도형순서의 각 원 점수를 합한 총점수(도형척도)를 사용하였다. K-CTONI-2의 세 소 검사의 원점수는 각각 25 점 만점으로 총 75 점 만점이다. 사회경제 적 요인의 경우 사례면담지를 통하여 얻은 가족 총인원 대비 수입 을 토대로 보건복지부가 지정한 차상위계층 이하에 대한 기준에 따라 일반과 저소득가정으로 나누었다.

통계분석은 SPSS version 25 프로그램을 이용하여, 음운인식 능 력과 조음능력, 언어능력(어휘), 인지(비구어 동작성 지능), 사회경 제적 수준 및 학년의 관계를 살펴보기 위해, 음운인식 과제에서 음 절점수와 음소점수를 각각 종속변수로 하고, REVT 수용점수, REVT 표현점수, APAC 원점수, K-CTONI-2 도형 과제 총점수, 사 회경제적 수준, 학년을 독립변수로 하여 상관분석과 단계식 중다회 귀분석(stepwise multiple regression)을 실시하였다.

\section{연구결과}

\section{학년별 음운인식, 조음, 어휘, 인지 점수}

1-3학년 아동의 합성 및 탈락 과제를 이용하여 음절과 음소수준 에서 살펴본 음운인식 결과는 Table 2 와 같다. 학년에 따른 음운인 
Table 2. Descriptive statistics of phonological awareness scores

\begin{tabular}{lcccc}
\hline & $\begin{array}{c}\text { 1st grade } \\
(\mathrm{N}=52)\end{array}$ & $\begin{array}{c}\text { 2nd grade } \\
(\mathrm{N}=54)\end{array}$ & $\begin{array}{c}\text { 3rd grade } \\
(\mathrm{N}=22)\end{array}$ & $\begin{array}{c}\text { Total } \\
(\mathrm{N}=128)\end{array}$ \\
\hline $\begin{array}{l}\text { PA-syllable } \\
\text { Raw score }\end{array}$ & $8.46(2.20)$ & $9.17(1.65)$ & $9.32(2.17)$ & $8.91(2.00)$ \\
$\begin{array}{l}\text { Percent } \\
\text { PA-phoneme }\end{array}$ & $84.62(22.00)$ & $91.67(16.45)$ & $93.18(21.68)$ & $89.06(19.97)$ \\
Raw score & $5.24(4.99)$ & $8.19(6.37)$ & $11.36(6.25)$ & $7.61(6.16)$ \\
Percent & $27.12(24.93)$ & $40.93(31.86)$ & $56.82(31.22)$ & $38.05(30.79)$ \\
\hline
\end{tabular}

Values are presented as mean (SD).

PA-syllable $=$ phonological awareness scores at the level of syllable; PA-phoneme $=$ phonological awareness scores at the level of phoneme.

Table 3. Results from articulation, language vocabulary, and nonverbal intelligence tests

\begin{tabular}{lcccc}
\hline & $\begin{array}{c}\text { 1st grade } \\
(\mathrm{N}=52)\end{array}$ & $\begin{array}{c}\text { 2nd grade } \\
(\mathrm{N}=54)\end{array}$ & $\begin{array}{c}\text { 3rd grade } \\
(\mathrm{N}=22)\end{array}$ & $\begin{array}{c}\text { Total } \\
(\mathrm{N}=128)\end{array}$ \\
\hline APAC & $2.65(4.21)$ & $0.96(1.79)$ & $1.36(1.97)$ & $1.72(3.11)$ \\
REVT & & & & \\
Expressive & $72.04(13.18)$ & $78.35(13.10)$ & $86.55(22.37)$ & $77.20(15.83)$ \\
Receptive & $74.44(15.15)$ & $83.78(16.00)$ & $90.91(20.29)$ & $81.21(17.46)$ \\
K-CTONI-2 & $29.31(9.65)$ & $35.50(10.03)$ & $37.27(13.12)$ & $33.29(10.91)$ \\
\hline
\end{tabular}

Values are presented as mean (SD).

APAC $=$ Assessment of Phonology \& Articulation for Children (Kim, Pae, \& Park, 2007); REVT=Receptive \& Expressive Vocabulary Test (Kim, Hong, Kim, Jang, \& Lee, 2009); K-CTONI-2=Korean Comprehensive Test of Nonverbal Intelligence second edition (Park, 2014).

식을 살펴보면 음절 수준에서는 1학년 아동 평균 $84.62 \%$ 로 비교적 높은 수행력을 보이고, 학년이 증가하면서 꾸준히 증가하여 3학년 에는 $93.18 \%$ 의 높은 정반응을 보였다. 반면에 음소 수준에서는 학 년이 증가함에 따라 꾸준히 증가하기는 하나 1학년이 $27.12 \%$ 이고, 2 학년은 $40.93 \%$ 로 $50 \%$ 미만의 낮은 수행력을 보였다. 3 학년은 평 균 $56.82 \%$ 로 $50 \%$ 이상이 되기는 하였으나 여전히 낮은 수행력을 보였다.

각 학년별 조음음운, 어휘, 인지능력을 살펴보기 위해 실시한 $\mathrm{APAC}, \mathrm{REVT}$ 표현 및 수용, K-CTONI-2 도형 과제 검사 결과는 Table 3과 같다. 조음능력과 관련해서 일부 아동이 치조마찰음 또 는 유음상의 오류, 자음군 단순화와 같은 오류를 1-3개 보였다. 표 현 및 수용어휘력과 인지능력은 학년이 증가함에 따라 꾸준히 증 가하였다.

\section{음운인식과 학년, 사회경제적 수준, 조음, 어휘 및 인지와의 상관관계}

음절 및 음소 수준에서의 음운인식과 학년, 사회경제적 수준, 조 음능력, 수용과 표현어휘 및 인지와의 관계를 살펴보고자 실시한
Table 4. Correlations between phonological awareness and other variables

\begin{tabular}{llllccc}
\hline & Grade & SES & APAC & $\begin{array}{c}\text { REVT- } \\
\text { Expressive }\end{array}$ & $\begin{array}{c}\text { REVT- } \\
\text { Receptive }\end{array}$ & $\begin{array}{c}\text { K-CTO- } \\
\text { NI-2 }\end{array}$ \\
\hline PA-syllable & $.175^{*}$ & $.178^{*}$ & $-.447^{* *}$ & $.496^{* *}$ & $.508^{* *}$ & $.422^{* *}$ \\
PA-phoneme & $.346^{* *}$ & .099 & $-.184^{*}$ & $.548^{* *}$ & $.538^{* *}$ & $.481^{* *}$ \\
\hline
\end{tabular}

$\mathrm{PA}=$ phonological awareness; $\mathrm{SES}=$ social-economic status; $\mathrm{APAC}=$ Assessment of Phonology \& Articulation for Children (Kim, Pae, \& Park, 2007); REVT= Receptive \& Expressive Vocabulary Test (Kim, Hong, Kim, Jang, \& Lee, 2009); K-CTONI-2=Korean Comprehensive Test of Nonverbal Intelligence second edition (Park, 2014). ${ }^{*} p<.05,{ }^{* *} p<.01$.

Table 5. Results of stepwise multiple regression

\begin{tabular}{lccccc}
\hline & $\mathrm{B}$ & $\beta$ & $R^{2}$ & $\Delta R^{2}$ & $F$ \\
\hline Syllable & & & & & \\
$\quad$ REVT-Receptive & .049 & .427 & .258 & .258 & $43.871^{* * *}$ \\
$\quad$ APAC & -.223 & -.347 & .372 & .114 & $22.681^{* * *}$ \\
Phoneme & & & & & \\
REVT-Expressive & .160 & .411 & .295 & .300 & $54.076^{* * *}$ \\
K-CTONI-2 & .157 & .278 & .349 & .059 & $11.436^{* *}$ \\
\hline
\end{tabular}

REVT $=$ Receptive \& Expressive Vocabulary Test (Kim, Hong, Kim, Jang, \& Lee, 2009); $A P A C=$ Assessment of Phonology \& Articulation for Children (Kim, Pae, \& Park, 2007); K-CTONI-2=Korean Comprehensive Test of Nonverbal Intelligence second edition (Park, 2014).

${ }^{*} p<.05,{ }^{* *} p<.01,{ }^{* * *} p<.001$.

상관분석의 결과는 Table 4 와 같다. 음소 수준에서의 음운인식과 사회경제적 수준과의 관계를 제외하고는 통계적으로 모두 유의한 상관관계를 보였다. 음운인식은 음절과 음소수준에서 모두 APAC 원점수와 부적 상관관계를 보이는 것으로 나타났고, 학년, REVT 수용과 표현점수와 K-CTONI-2 원점수와 정적 상관관계를 보였 다. 이 중 음절 수준에서는 수용어휘점수와 음운인식의 상관계수 가 .508로 가장 높게 나타났으며, 음소 수준에서는 수용과 표현어 휘점수 모두 상대적으로 높은 상관계수를 보이기는 했으나. 548 로 표현어휘점수가 요인 중에서 가장 높은 상관관계를 보였다.

\section{음운인식 예측 변인}

음절 및 음소 수준에서 아동의 음운인식을 가장 잘 예측하고 설 명하는 변인이 무엇인지 찾기 위해 단계식 중다회귀분석을 실시한 결과는 Table 5 와같다.

음절 수준에서는 학년, 사회경제적 수준, 조음, 수용 및 표현어휘, 인지능력을 나타내는 변인 중에 REVT 수용어휘점수가 음운인식 을 $25.8 \%$ 로 가장 잘 설명하였고, $\mathrm{APAC}$ 원점수가 부가적으로 $11.4 \%$ 설명하였다. 음소 수준에서는 음절 수준의 결과와는 다르게 REVT 표현어휘점수가 음운인식을 $30 \%$ 로 가장 잘 설명하였고, 다음으로 K-CTONI-2 점수가 $5.9 \%$ 로 음운인식을 부가적으로 설명하였다. 


\section{논의 및 결론}

본 연구는 초등학교 저학년 아동의 음운인식과 말.언어, 인지, 사 회경제적 수준, 학년과의 관계를 살펴보고 음절과 음소 수준에서 의 음운인식을 가장 잘 설명하는 요인을 찾고자 하였다. 음운인식 과 다른 요인과의 관계를 살펴보기에 앞서서 초등학교 1-3학년 아 동의 음운인식 발달 현황을 살펴보면 음절 수준에서는 1 학년 아동 이 평균 $80 \%$ 이상의 높은 수행력을 보여, 초등학교 저학년 아동의 음절에 대한 음운인식은 전반적으로 완성단계에 있음을 보여주었 다. 반면에 음소 수준에서는 $1,2,3$ 학년이 각각 $27 \%, 40 \%, 56 \%$ 의 정 반응을 보여, 학년이 증가함에 따라 꾸준히 증가하기는 하나 전반 적으로 낮은 수행력을 보였다. 이러한 음절과 음소 수준에서의 발 달 현황은 한국아동의 음운인식 발달을 살펴본 국내연구와 거의 동일하다. 특히 음소 수준에서의 음운인식은 비교적 오랜 기간 동 안 서서히 발달이 되어 4 학년에 이르러 $75 \%$ 이상의 정반응을 보였 다는 Kim과 $\mathrm{Pae}$ (2007)의 연구와 일관성이 있다.

음운인식과 각 요인 간 상관분석 결과를 살펴보면 음절과 음소 수준에서의 음운인식은 모두 아동의 학년과 조음능력, 수용 및 표 현어휘력, 인지와 상관관계를 보였다. 사회경제적 수준과 음절 수 준에서의 음운인식의 관계는 유의미하기는 했으나 상관계수가 .178로 낮았으며, 음소 수준에서는 통계적으로 유의미하지 않았다. 이러한 결과는 부모의 사회경제적 수준이 아동의 음운인식에 영향 을 미치는 부분은 비교적 적고, 기타 다른 변인에 의해 영향을 받는 다고 주장한 선행연구(MacLean et al., 1987; Raz \& Bryant, 1990) 를 지지하는 결과라 할 수 있다. 요컨대 부모의 사회경제적 수준의 영향을 완전히 배제할 수는 없으나 환경적 요인보다는 아동의 말. 언어, 인지와 같은 내적 요인이 보다 더 음운인식을 설명한다고 할 수 있다. 그러나 본 연구에서는 부모의 소득 수준에 따라 사회경제 적 수준을 비교적 단순하게 이분법적으로 나누어 살펴보았기 때문 에 이와 관련된 결과해석에 주의를 기울여야 한다. 즉 부모의 소득 이 보건복지부가 지정한 차상위계층 이하에 속할 경우 저소득으로 배치하고 상위나 중위 수준에 대한 구분 없이 단순히 두 집단으로 나누어서 살펴보았기 때문에 사회경제적 수준과 음운인식과의 관 계를 살펴보는 데는 민감함이 떨어질 수 있다. 추후 연구에서는 부 모의 소득 수준, 교육력 및 직업 영역에 걸쳐서 사회경제적 수준을 보다 더 세밀하고, 타당하게 반영하는 지표를 이용하여 사회경제 적 수준과 음운인식과의 관계를 살펴볼 필요가 있겠다.

단계식 중다회귀분석을 실시한 결과는 음절과 음소 수준에서의 음운인식은 각각 서로 다른 요인에 의해 설명되는 것으로 나타났 다. 음절수준에서는 학년, 사회경제적 수준, 조음, 수용 및 표현어휘
능력, 인지를 나타내는 변인 중에 REVT 수용어휘점수가 음운인식 을 $25.8 \%$ 로 가장 잘 설명하였고, $\mathrm{APAC}$ 원점수가 부가적으로 $11.4 \%$ 설명하였다. 즉 음절 수준에서의 음운인식은 아동의 수용어휘력과 조음능력이 유의하게 설명하였다. 음소수준에서는 REVT 표현어휘 점수가 음운인식을 $30 \%$ 로 가장 잘 설명하였고, 다음으로 K-CTO$\mathrm{NI}-2$ 점수가 5.9\%로 음운인식을 부가적으로 설명하는 것으로 나 타나, 음소 수준의 음운인식은 표현어휘력과 인지가 유의하게 설명 하였다. 음절과 음소 수준에서의 음운인식은 모두 공통적으로 수 용 및 표현어휘력과 유의한 관계를 보인다. 이러한 결과는 일반적인 언어능력과 함께 어휘량(vocabulary size)이 아동의 현재 음운인식 능력을 잘 설명하거나, 후에 발달하는 양상을 가장 잘 예측한다는 선행연구와 일치하는 결과이다(Rvachew, 2006; Silvén, Niemi, \& Voeten, 2002; Walley, Metsala, \& Garlock, 2003).

어휘력이 음절과 음소 수준에서의 음운인식을 공통적으로 설명 하지만 부가적으로 음운인식을 설명하는 요인에는 차이를 보였다. 음절수준에서는 아동의 조음능력이 부가적인 설명력이 있었으나 음소 수준에서는 조음능력보다는 인지가 음운인식을 부가적으로 유의하게 설명하였다. 이러한 결과는 음절보다는 음소 수준에서 음운정보를 기억하고, 처리하고, 조작하여 음운인식 과제를 수행 할 때 인지적인 부담이 훨씬 크기 때문에, 아동의 인지가 음소 수준 의 음운인식 수행력에 중요한 역할을 한다는 것을 의미한다. 조음 능력이 음절 수준에서 음운인식을 설명하는 것으로 나타나기는 했 으나 상대적으로 그 설명력이 약하고, 음소수준에서는 유의하지 않았다. 이러한 결과는 일부 말소리장애 아동만이 음운인식상의 어려움을 보이는 점과 연결하여 해석해 볼 수 있다. 말소리장애와 음운인식 간의 관계를 살펴본 선행연구는 음운인식상의 문제는 모 든 말소리장애 아동에게 관찰되는 것이 아닌 일부 말소리장애 아 동만이 관찰된다고 보고하고 있다. 음운 표상상의 문제로 인해 말 소리 산출의 어려움을 보이거나, 여러 개의 음소에서 오류를 보여 말명료도가 심하게 손상된 아동의 경우 음운인식상의 어려움을 함께 보인다. 특히 언어장애를 동반한 말소리장애 아동의 경우에 음운인식상의 어려움을 보이고 이후 읽기장애로 문제가 확산되는 경향이 있다(Anthony et al., 2011; Nathan et al., 2004; Preston \& Edwards, 2010; Schuele, 2004). 이러한 해석 외에 본 연구의 조음능 력과 음운인식 간의 결과는 조음능력을 살펴본 맥락과 측정치의 제한점을 고려해야 한다. 본 연구에 참여한 대부분의 학령기 아동 은 조음음운 발달이 완성되어 $\mathrm{APAC}$ 상에서 오류를 전혀 보이지 않았거나, 오류를 보인 경우도 대부분 1-3개의 음소에서만 오류를 보였다. 따라서 천정효과(ceiling effect)를 보인 APAC 원점수를 바 탕으로 아동의 조음능력을 살펴본 점이 결과에 영향을 미친 연구 
의 제한점이라 할 수 있다. 따라서 추후 연구에서는 조음능력을 좀 더 세부적이고 심도깊게 살펴볼 수 있는 평가 맥락과 측정치를 이 용해서 말소리장애 아동을 대상으로 음운인식과 다른 여러 변인 간의 관계를 면밀하게 살펴보는 것이 필요하다.

연구결과를 종합해보면, 아동의 음운인식은 말·언어 능력과 인 지와 복합적으로 상호작용하면서 발달한다고 할 수 있다. 이러한 음운인식과 다양한 변인간의 복합적인 관계는 추후 보다 많은 수 의 대상자를 확보하고 구조 방정식 모형 등의 분석을 통해 심도깊 게 살펴볼 필요가 있겠다. 본 연구결과는 아동이 표현 및 수용어휘 력이 떨어지거나, 조음 확도가 떨어질 경우 읽기력을 가장 잘 예측 하는 음절 및 음소 수준에서의 음운인식에도 문제를 보일 가능성 이 높음을 제안하고 있다. 학업을 효율적으로 수행할 수 있는 말.언 어 능력을 갖추는 것은 아동 언어중재서비스의 중요한 목표 중의 하나이다. 따라서 학령전기에 언어나 조음상의 발달 지연이나 문제 를 보이는 아동이 학령기에 읽기와 학습상의 문제를 부차적으로 보이지 않기 위해서는 학령전기에 언어와 조음능력을 정상화하거 나, 최대한 향상시켜야 한다. 또한 언어와 조음중재서비스를 제공 하는 동안 음운인식 프로그램을 함께 접목하여 아동의 음운인식 이 향상될 수 있게, 음운인식 기술을 보다 더 적극적이고 직접적으 로 중재하여 후에 발생할 수 있는 읽기장애를 예방하는 것이 필요 하겠다.

\section{REFERENCES}

Ahn, S. W., Heo, M. J., Kim, Y., \& Kim, M. K. (2011). Development of phonological awareness in Korean children aged between 4-7 throughout Korea. Journal of Speech-Language and Hearing Disorders, 20(3), 121-141.

Ahn, S. W., Lee, C. H., Kim, Y., Shin, Y., J., \& Park, W., K. (2007). A study of the effect of parent's social economic status on phonological awareness ability in children. Journal of Special Education: Theory and Practice, 8(3), 533-550.

Ahn, S., \& Shin, Y. (2008). A compare study of multi-cultural background children's and low-income children's phonological awareness ability. Journal of Speech \& Hearing Disorders, 17(4), 81-94.

Anthony, J. L., Aghara, R. G., Dunkelberger, M. J., Anthony, T. I., Williams, J. M., \& Zhang, Z. (2011). What factors place children with speech sound disorders at risk for reading problems? American Journal of Speech-Language Pathology, 20(2), 146-160.

Berthal, J., Bankson, N., Flipsen, P. (2017). Articulation and phonological disorders: speech sound disorders in children (8th ed.). Boston, MA: Pearson.
Bird, J., Bishop, D. V., \& Freeman, N. H. (1995). Phonological awareness and literacy development in children with expressive phonological impairments. Journal of Speech, Language, and Hearing Research, 38(2), 446-462.

Bradley, L., \& Bryant, P. E. (1983). Categorizing sounds and learning to read: a causal connection. Nature, 301(5899), 419-421.

Burt, L., Holm, A., \& Dodd, B. (1999). Phonological awareness skills of 4-yearold British children: an assessment and developmental data. International Journal of Language \& Communication Disorders, 34(3), 311-335.

Cho, J. R., \& McBride-Chang, C. (2005). Correlates of Korean Hangul acquisition among kindergartners and second graders. Scientific Studies of Reading, 9(1), 3-16.

Gillon, G. T., \& Schwarz, I. E. (2001). Screening New Zealand children's spoken language skills for academic success. Proceedings of the 2001 Speech Pathology Australia National Conference: Evidence and Innovation, 207214.

Hogan, T. P., Catts, H. W., \& Little, T. D. (2005). The relationship between phonological awareness and reading. Language, Speech, and Hearing Services in Schools, 36(4), 285-293.

Hong, S. I., Jeon, S. I., Pae, S., \& Lee, I. (2002). Development of phonological awareness in Korean children. Korean Journal of Communication \& Disorders, 7(1), 49-64.

Hong. S. I. (2001). The development of phonological awareness in Korean children (Master's thesis). Yonsei University, Seoul, Korea.

Kim, A. H. (2007). Review of phonological awareness assessment. Journal of Special Education: Theory and Practice, 8(2), 139-167.

Kim, A., H., Yoo, H., S., \& Kim, U., J. (2010). An exploratory study on the structure of phonological awareness in 5- to 8-year-old children. The Journal of Elementary Education, 23(3), 173-192.

Kim, J. K., Shin, J. H., \& Ahn, S. W. (2005). A study of comparison in phonological awareness ability between articulatorily phonologically disabled children and normal children. Journal of Special Children Education, 7(4), 93-108.

Kim, K. B., Kim, K. J., Kwon, S. B., \& Lee, K. D. (2007). A comparative study of phonological awareness ability between articulatorily-disordered and phonologically-disordered preschool children. Speech Sciences, 14(3), 161176.

Kim, M. B., \& Pae, S. (2007). Word recognition and phonological awareness of kindergartener, second and fourth graders. Journal of Speech-Language \& Hearing Disorder, 16(2), 89-107.

Kim, M. J., Pae, S., \& Park, C. I. (2007). Assessment of Phonology and Articu- 
lation for Children (APAC). Incheon: Human Brain Research \& Consulting Co.

Kim, Y. T., Hong, G. H., Kim, K. H., Jang, H. S., \& Lee, J. Y. (2009). Receptive \& expressive vocabulary test (REVT). Seoul: Seoul Community Rehabilitation Center.

Ko, Y. K., \& Kim, S. J. (2010). A comparison of phonological awareness and reading ability between children with and without functional articulatory and phonological disorders. Korean Journal of Communication \& Disorders, 15(2), 157-167.

Larrivee, L. S., \& Catts, H. W. (1999). Early reading achievement in children with expressive phonological disorders. American Journal of Speech-Language Pathology, 8(2), 118-128.

Lee, K. E., \& Ha, J. W. (2018). Phonological short-term and working memory in 5-and 6-year-old children with speech sound disorders. Communication Sciences \& Disorders, 23(3), 713-724.

Lewis, B. A., O’Donnell, B., Freebairn, L. A., \& Taylor, H. G. (1998). Spoken language and written expression: interplay of delays. American Journal of Speech-Language Pathology, 7(3), 77-84.

Lonigan, C. J., Burgess, S. R., Anthony, J. L., \& Barker, T. A. (1998). Development of phonological sensitivity in 2-to 5-year-old children. Journal of Educational Psychology, 90(2), 294-311.

Maclean, M., Bryant, P., \& Bradley, L. (1987). Rhymes, nursery rhymes, and reading in early childhood. Merrill-Palmer Quarterly, 33(3), 255-281.

McDowell, K. D., Lonigan, C. J., \& Goldstein, H. (2007). Relations among socioeconomic status, age, and predictors of phonological awareness. Journal of Speech, Language, and Hearing Research, 50(4), 1079-1092.

Nathan, L., Stackhouse, J., Goulandris, N., \& Snowling, M. J. (2004). The development of early literacy skills among children with speech difficulties. Journal of Speech, Language, and Hearing Research, 47(2), 377-391.

Pae, S., Kim, M., Yoon, H. J., \& Jang, S. (2015). Korean Language Based Read- ing Assessment (KOLRA). Seoul: Hakjisa.

Park, H. (2014). Korean version of Comprehensive Test of Nonverbal Intelligence Second Edition (K-CTONI-2). Seoul: Mindpress.

Preston, J., \& Edwards, M. L. (2010). Phonological awareness and types of sound errors in preschoolers with speech sound disorders. Journal of Speech, Language, and Hearing Research, 53(1), 44-60.

Raz, I. S., \& Bryant, P. (1990). Social background, phonological awareness and children's reading. British Journal of Developmental Psychology, 8(3), 209-225.

Rvachew, S. (2006). Longitudinal predictors of implicit phonological awareness skills. American Journal of Speech-Language Pathology, 15(2), 165176.

Schuele, C. M. (2004). The impact of developmental speech and language impairments on the acquisition of literacy skills. Mental Retardation and Developmental Disabilities Research Reviews, 10(3), 176-183.

Silvén, M., Niemi, P., \& Voeten, M. J. (2002). Do maternal interaction and early language predict phonological awareness in 3-to 4-year-olds? Cognitive Development, 17(1), 1133-1155.

Torgesen, J. K., Wagner, R. K., \& Rashotte, C. A. (1994). Longitudinal studies of phonological processing and reading. Journal of Learning Disabilities, 27(5), 276-286.

Walley, A. C., Metsala, J. L., \& Garlock, V. M. (2003). Spoken vocabulary growth: Its role in the development of phoneme awareness and early reading ability. Reading and Writing, 16(1-2), 5-20.

Whitehurst, G. J., \& Lonigan, C. J. (1998). Child development and emergent literacy. Child Development, 69(3), 848-872.

Wimmer, H., Landerl, K., Linortner, R., \& Hummer, P. (1991). The relationship of phonemic awareness to reading acquisition: more consequence than precondition but still important. Cognition, 40(3), 219-249. 


\section{국문초록}

\section{초등학교 저학년 아동의 음운인식과 관련 요인 연구}

하승희 ${ }^{1} \cdot$ 소금빈 ${ }^{2}$

'한림대학교 언어청각학부, 한림청각언어연구소, ${ }^{2}$ 한림대학교 일반대학원 언어청각학과 언어병리전공

배경 및 목적: 단어의 음운구조를 알고 조작할 수 있는 능력을 의미하는 음운인식은 초기 읽기 능력과 강한 상관관계를 보인다. 음운인 식은 아동의 연령뿐만 아니라 아동의 말언어, 인지, 환경과 긴밀한 관계를 보이며 발달한다. 본 연구는 초등학교 저학년 아동의 음운인 식과 말언어, 인지, 사회경제적 요인과의 관계를 살펴보고 음절과 음소 수준에서의 음운인식을 가장 잘 설명하는 요인을 찾고자 하였 다. 방법: 초등학교 저학년인 1-3학년 아동 총 128명을 대상으로 음운인식, 수용 및 표현어휘, 조음, 인지 영역에서의 검사를 실시하고, 아동 가정의 사회경제적 수준에 대한 정보를 수집하였다. 음운인식 과제에서 음절점수와 음소점수를 각각 종속변수로 하고, APAC 원 점수, REVT 수용 및 표현점수, K-CTONI-2 도형과제점수, 사회경제적 수준, 학년을 독립변수로 하여 상관분석과 단계식 중다회귀분석 을 실시하였다. 결과: 음절과 음소 수준 모두에서 음운인식은 APAC 원점수, REVT 수용과 표현점수, K-CTONI-2 도형과제점수 및 연 령과 상관관계를 보였다. 회귀분석 결과, 음절 수준에서는 아동의 REVT 수용점수와 APAC 원점수가, 음소 수준에서는 REVT 표현점 수, K-CTONI-2 도형과제점수와 학년이 음운인식을 유의하게 설명하였다. 논의 및 결론: 본 연구는 초등학교 저학년 아동의 음운인식 은 수용 및 표현어휘력, 조음능력, 인지와 밀접한 관계를 맺으며 발달해 나감을 제시하고 있다.

핵심어: 음운인식, 조음음운, 수용 및 표현어휘, 비언어성 지능, 사회경제적 수준

\section{참고문헌}

고유경, 김수진(2010). 기능적 조음음운장애아동과 일반아동의 음운인식과 읽기능력의 비교 및 상관. 언어청각장애연구, 15(2), 157-167. 김기범, 김기주, 권순복, 이강대(2007). 취학전 조음장애와음운장애 아동의 음운인식 능력 비교. 음성과학, 14(3), 161-176. 김미배, 배소영(2007). 유치원, 초등 2,4 학년의 낱말재인 및 음운인식 능력. 언어치료연구, 16(2), 89-107. 김민정, 배소영, 박창일(2007). 아동용 발음평가(APAC). 인천: 휴브알앤씨. 김애화(2007). 국내 음운인식 검사도구 개발을 위한 선행 검사도구 분석. 특수교육저널: 이론과 실천, 8(2), 139-167. 김애화, 유현실, 김의정(2010). 취학전 및 초등학교 1학년 아동의 음운인식 구조 탐색 연구. 초등교육연구, 23(3), 173-192. 김영태, 홍경훈, 김경희, 장혜성, 이주연(2009). 수용·표현어휘력검사(REVT). 서울: 서울장애인종합복지관. 김자경, 신지현, 안성우(2005). 조음 및 음운장애아동과 일반아동간의 음운인식능력 비교. 특수아동교육연구, 7(4), 93-108. 박혜원(2014). 한국 비언어지능검사 2판(K-CTONI-2). 서울: 마인드프레스. 배소영, 김미배, 윤효진, 장승민(2015). 한국어 읽기검사(KOLRA). 서울: 학지사. 안성우, 신영주(2008). 저소득층 일반 아동과 다문화 가정 아동의 음운인식능력 비교 연구 언어치료연구, 17(4), 81-94.

안성우, 이창환, 김유, 신영주, 박원경(2007). 부모의 사회, 경제적 지위에 따른 아동들의 음운인식수행 능력 비교 연구. 특수교육저널: 이론과 실천, 8(3), 533-550.

안성우, 허민정, 김유, 김미경(2011). 4세-7세 유아의 음운인식능력 발달 특성에 대한 대(규모) 집단 연구. 언어치료연구, 20(3), 121-141. 이기은, 하지완(2018). 5세와 6세 말소리장애 아동의 음운단기기억과 음운작업기억 능력. Communication Sciences \& Disorders, 23(3), 713-724. 홍성인(2001). 한국아동의 음운인식발달. 연세대학교 대학원 석사학위논문. 홍성인, 전세일, 배소영, 이익환(2002). 한국 아동의 음운인식 발달. 언어청각장애연구, 7(1), 49-64.

\section{ORCID}

하승희(제1저자, 교신저자, https://orcid.org/0000-0003-2133-3720); 소금빈(공동저자, https://orcid.org/0000-0001-7080-503X) 